\title{
PENGUATAN KERANGKA HUKUM ASEAN UNTUK MEWUJUDKAN MASYARAKAT EKONOMI ASEAN 2015
}

(Strengthening the Legal Framework to Realizing ASEAN Economic Community 2015)

\author{
Subianta Mandala \\ Pusat Dokumentasi, Jaringan, dan Informasi Hukum Nasional \\ Badan Pembinaan Hukum Nasional \\ Email: subianta@hotmail.com
}

Naskah diterima: 27 Juni 2014; revisi: 21 Agustus 2014; disetujui: 25 Agustus 2014

\begin{abstract}
Abstrak
Negara negara anggota ASEAN pada umumnya kurang menyukai pendekatan yang terlalu legalistik dalam hubungan diantara mereka, dan cenderung memilih pendekatan "ASEAN Way" yaitu melalui konsensus atau musyawarah untuk mufakat. Namun demikian, menjelang terbentuknya Masyarakat Ekonomi ASEAN pada tahunn 2015, ASEAN perlu mengembangkan model pendekatan yang berlandaskan aturan hukum (rules-based). Pendekatan hukum tersebut diharapkan dapat digunakan tidak saja dalam kerangka merumuskan kesepakatan-kesepakatan yang dibuat oleh ASEAN yang umumnya dibuat dalam perjanjian atau persetujuan ASEAN, namun juga untuk menyelesaikan sengketa-sengketa yang timbul diantara anggota negara negara ASEAN dalam mengimplementasikan kewajiban-kewajiban yang lahir dari kesepakatan atau perjanjian yang dibuat diantara mereka. ASEAN secara bertahap mulai mengembangkan kerangka hukum dalam melakukan kerjasama ekonomi yang berlangsung diantara anggota negara-negara ASEAN. Tulisan ini mencoba mengkaji lebih dalam langkah-langkah yang telah diambil oleh ASEAN dalam upaya mereka mempererat kerjasama ekonominya, dan kajian tersebut dilakukan dalam perspektif pengembangan kerangka hukum sebagai landasan bagi kerjasama ekonomi di ASEAN. Mengingat bahwa kerangka hukum yang dimasudkan disini bukan saja menyangkut pembentukan substansi hukum, tetapi juga meliputi penyelesaian sengketa, tulisan ini juga membahas mekanisme penyelesaian sengketa yang tersedia di internal ASEAN.

Kata Kunci: kerangka hukum, kerjasama ekonomi, kesepakatan
\end{abstract}

\section{Abstract}

The members of ASEAN have been reluctant to be too "legalistic" in their relations with each other, preferring to conduct their relationships in "ASEAN Way" or by consensus. Given that ASEAN would become the ASEAN Economic Community in 2015, it is very important that appropriate legal-based mechanism should be developed to establish laws and resolve disputes relating to trade and investment in the region. ASEAN have been moving slowly towards developing legal framework for economic cooperation among the member state of ASEAN. This paper examines the various steps which have been taken towards economic cooperation in the region and, examines them in the context of the evolving legal framework for economic cooperation in ASEAN. As dispute will inevitably arise in any relationship, one of the elements of any any legal system is to provide a means for settling these disputes. This paper, therefore, also examines the various mechanisms for dispute resolution available in intra-ASEAN.

Keywords: legal framework, economic cooperation, consensus 


\section{A. Pendahuluan}

ASEAN adalah sebuah organisasi regional yang beranggotakan negara-negara yang terletak di kawasan Asia tenggara dengan cakupan wilayah sekitar 4.46 juta kilometer persegi, dan dengan jumlah penduduk kurang lebih sekitar 600 juta. ${ }^{1}$ ASEAN didirikan berdasarkan Deklarasi Bangkok pada tanggal 8 Agustus 1967 oleh 5 (lima) negara, yaitu: Indonesia, Malaysia, Philipina, Singapura dan Thailand. Selanjutnya keanggotaannya diperluas menjadi 10 negara dengan masuknya Brunei Darussalam (1984), Vietnam (1995), Laos, Myanmar (1997) dan Kamboja (1999).

Usaha pembentukan organisasi regional di Asia tenggara, sebelum terbentuknya ASEAN, selalu mengalami kegagalan. Sejak berakhirnya Perang Dunia ke-2, terdapat beberapa usaha pembentukan organisasi regional, yang dimulai dengan usulan pembentukan Pan Southeast Asian Union oleh Perancis, namun gagal setelah adanya kudeta di Thailand pada tahun 1948. Selanjutnya, pada tahun 1950 ada upaya pembentukan Asian Union, yang ditujukan untuk kerjasama non-militer, dan dalam Konferensi di Bandung tahun 1955 ditegaskan perlunya kerjasama ekonomi regional. Namun keinginan ini tidak dapat terealisir. Kerjasama di bidang pertahanan, dan dengan tambahan kerjasama peningkatan ekonomi dan kesejateraan sosial, pernah diusahakan di kawasan Asia tenggara dengan dibentuknya Southeast Asia Treaty Organization (SEATO) pada tahun 1954. Namun kerjasama inipun gagal. Pada tahun 1962, Maphilindo, yang terdiri dari Malaysia, Philipina, dan Indonesia dibentuk. Organisasi ini yang didasarkan pada solidaritas etnis inipun akhirnya menemui kegagalan ketika dilancarkannya Konfrontasi oleh Indonesia terhadap Malaysia. Pada tahun yang sama juga dibentuk Association of Southeast Asia (ASA) yang beranggotakan Philipina, Malaysia dan Thailand, yang kemudian juga gagal berkembang karena memburuknya hubungan diplomatik antara Malaysia dan Philipina menyangkut isu Sabah pada tahun 1963. Kegagalan demi kegagalan tersebut tidak lepas dari tidak stabilnya hubungan diplomatik antar negara di kawasan dan pertikaian menyangkut teritorial setelah ditinggalkan oleh kekuatan penguasa Barat. Sekalipun semua upaya pembentukan organisasi atau kerjasama regional sebagaimana digambarkan di atas mengalami kegagalan, namun upaya tersebut mempunyai kontribusi bagi pembentukan ASEAN. ${ }^{2}$ Belajar dari pengalaman sebelumnya, negara-negara di kawasan Asia tenggara semakin memahami perbedaan kepentingan dan masalah masalah yang dihadapi negaranegara lain. ${ }^{3}$ Membaiknya hubungan antara Malaysia dengan Indonesia, menyusul pergantian pemerintahan dari Soekarno kepada Soeharto, memberikan jalan bagi pembentukan organisasi ASEAN pada tahun 1967. 
Tujuan dibentuknya ASEAN, sebagaimana disebutkandalamDeklarasiBangkok, diantaranya adalah (1) untuk mempercepat pertumbuhan ekonomi, kemajuan sosial dan pengembangan budaya di kawasan melalui upaya bersama dengan didasari oleh semangat kesetaraan dan kebersamaan untuk memperkuat fondasi bagi sebuah masyarakat ASEAN yang makmur dan damai, (2) mempromosikan kerjasama yang erat dan saling membantu mengenai masalahmasalah yang menjadi kepentingan bersama di bidang ekonomi, sosial, budaya, teknis, ilmu pengetahuan dan administrasi, dan (3) untuk mengefektifkan kerjasama pemanfaatan pertanian dan industri, dan perluasan perdagangan, termasuk mengkaji perdagangan komoditas internasional. ${ }^{4}$

Berdasarkan uraian di atas, kerjasama ekonomi merupakan salah satu bidang yang menjadi tujuan pembentukan ASEAN. Dengan demikian, kerjasama ekonomi bukan satu satunya dan juga bukan tujuan utama dari pembentukan ASEAN. Bahkan pada periode awal pembentukannya, ASEAN lebih banyak fokus pada hal hal yang bersifat non ekonomi. ${ }^{5}$ Dalam perkembangannya, ASEAN banyak memberikan perhatian pada kerjasama ekonomi. Hal ini dapat dilihat dari langkah langkah yang telah diambil oleh ASEAN dalam mewujudkan kerjasama ekonomi, termasuk pembuatan perjanjian internasional yang menjadi landasan hukum bagi berbagai kegiatan kerjasama dalam pembangunan industri, perdagangan dan investasi. Perkembangan kerjasama ekonomi ASEAN, yang dewasa ini diarahkan kepada pembentukan Masyarakat Ekonomi ASEAN, berjalan relatif lebih cepat dibandingkan dengan kerjasama di bidang politik-keamanan dan sosial budaya.

Perkembangan penting yang terjadi di dalam ASEAN saat ini adalah ditanda-tanganinya Piagam ASEAN pada bulan Nopember 2007 yang mengindikasikan komitmen negara-negara ASEAN untuk memperkuat kerjasama regional melalui pembentukan Masyarakat ASEAN (ASEAN Community) yang lebih terintegrasi yang diharapkan terwujud pada tahun 2015. Dalam Mukadimah Piagam ASEAN ${ }^{6}$ disebutkan bahwa Masyarakat ASEAN akan ditopang oleh 3 pilar yaitu Masyarakat Politik-Keamanan ASEAN, Masyarakat Ekonomi ASEAN, dan Masyarakat Sosial Budaya ASEAN.

Selama ini ASEAN sebagai perhimpunan regional, ikatannya terlalu longgar, pengambilan keputusan dilakukan secara konsensus dan pelaksanaannya diserahkan sepenuhnya kepada masing-masing negara anggota. ASEAN menyadari bahwa berbagai perjanjian ASEAN telah dihasilkan, akan tetapi tidak ada sanksi bagi mereka yang tidak mematuhinya. Sebagai sebuah asosiasi yang relatif longgar, proses pengambilan keputusan berdasarkan konsensus kerap dirasakan menghambat gerak ASEAN untuk maju lebih cepat. Akibatnya, berbagai

4 The Asean Declaration (Bangkok Declaration) Bangkok, 8 August 1967, diakses melalui http://www.asean.org/ news/item/the-asean-declaration-bangkok-declaration, (diakses 3 April 2014).

5 Lihat Paul J. Davidson, ASEAN-The Evolving Legal Framework fo Economic Cooperation, (Singapore: Times Academic Press, 2002), hlm. 1.

6 Piagam ASEAN ditanda-tangani oleh 10 Kepala Negara/Pemerintahan ASEAN tanggal 20 Nopember 2007 pada KTT ke-13 di Singapore dan mulai berlaku efektif tanggal 15 Desember 2008 setelah kesepuluh Negara anggota ASEAN menyampaikan instrument ratifikasi. 
permasalahan di kawasan ASEAN sering diselesaikan dengan the "ASEAN Way" (cara ASEAN), satu putusan kompromistis yang paling bisa diterima seluruh negara anggota ASEAN, akan tetapi banyak mengandung kelemahan.

Tantangan yang dihadapi oleh ASEAN sekarang ini adalah meningkatnya persaingan global dan proteksionisme. Integrasi regional yang lebih kuat dan efektif akan meningkatkan daya tarik bagi penanaman modal asing dan juga meningkatkan daya saing dalam kancah ekonomi dan perdagangan global. Salah satu tantangan penting dewasa ini yang dihadapi oleh ASEAN adalahmelakukan penguatan kerangka hukum untuk menun jang terwujudnya integrasi regional. Penggunaan kerangka hukum dalam melaksanakan kerjasama ekonomi baik yang bersifat regional maupun internasional sudah menjadi kecendurang global dewasa ini, misalnya dikeluarkannnya berbagai instrumen hukum yang bersifat mengikat dalam konteks Uni Eropa (EU) dan Organisasi Perdagangan Dunia (WTO). Kerangka hukum memberikan aturan dalam hubungan atau interaksi antar anggota dalam satu komunitas dan mekanisme untuk menyelesaikan sengketa diantara para anggota dalam melaksanakan aturan yang ada tersebut. Dengan demikian, ada dua aspek ketika kita berbicara mengenai kerangka hukum, yaitu (1) menyangkut pembuatan substansi hukum, dan (2) penyelesaian sengketa atau mekanisme penegakan hukum. Tulisan ini akan mencoba mengeksplor berbagai macam langkah yang telah diambil untuk meningkatkan kerjasama ekonomi di ASEAN dan mengkajinya dalam konteks pengembangan kerangka hukum sebagai landasan bagi kerjasama ekonomi di ASEAN. Bahasan menyangkut kerangka hukum akan mencakup 2 (dua) aspek yaitu pembentukan kerangka substansi hukum dan mekanisme penyelesaian sengketa yang tersedia di ASEAN.

\section{B. Metode Penelitian}

Untuk mengkaji permasalahan di atas, penulis menggunakan metode penelitian hukum normatif (yuridis normatif). Penelitian ini menitikberatkan pada studi literatur. Keseluruhan data yang diperoleh dianalisa secara kualitatif dan diberikan penggambaran (deskripsi) secara mendalam mengenai perubahan pendekatan yang diambil oleh ASEAN, dari pendekatan soft law ke hard law.

\section{Pembahasan}

\section{Kerangka Hukum dalam Mewujudkan Masyarakat Ekonomi ASEAN}

Langkah penting pertama menuju kerjasama ekonomiASEANadalahpenandatangan Deklarasi ASEAN Concord pada saat dilaksanakannya Pertemuan Puncak Pertama ASEAN (The First ASEAN Summit) di Bali pada tahun 1976. Perjanjian tersebut, yang menjadi dasar bagi kerjasama ASEAN di bidang perdagangan dan industri, kemudian diikuti oleh perjanjian perjanjian lainnya yang mengatur lebih rinci berbagai kegiatan kerjasama pembangunan industri dan perdagangan, salah satunya adalah Persetujuan ASEAN mengenai Pengaturan Perdagangan Preferensial (Agreement on ASEAN Preferential Trading Arrangements atau PTA) yang dibuat pada tahun 1977. Persetujuan ini memberikan kesempatan kepada negara-negara anggota ASEAN untuk memperluas preferensi perdagangan diantara mereka berdasarkan ketentuan dan aturan yang tercakup dalam 
persetujuan. ${ }^{7}$ Preferensi perdagangan ini diberikan diantaranya kepada proyek proyek industri ASEAN yang berskala besar yang tercakup dalam Proyek Industri ASEAN (ASEAN Industrial Project atau disingkat AIP). AIP ini adalah persetujuan menyangkut pengalokasian kegiatan industri tertentu kepada satu negara anggota ASEAN dalam jangka waktu yang disepakati. Preferensial tarif diberikan terhadap produk produk dari kegiatan proyek tersebut.

Langkah penting berikutnya dalam kerangka kerjasama ekonomi ASEAN adalah keputusan yang diambil dalam Pertemuan Puncak ASEAN ke-4 pada tahun 1992 di Singapura, yaitu kesepakatan untuk membentuk Kawasan Perdagangan Bebas ASEAN (ASEAN Free Trade Area) atau AFTA. Gagasan pembentukan wilayah perdagangan bebas di ASEAN adalah sebuah langkah besar yang mengubah ASEAN dari yang fokus utamanya pada perdamaian dan stabilitas menuju kepada perluasan dan peningkatan kerjasama ekonomi. ${ }^{8}$ AFTA merupakan wujud dari kesepakatan dari negara-negara ASEAN untuk membentuk suatu kawasan bebas perdagangan dalam rangka meningkatkan daya saing ekonomi kawasan regional ASEAN dengan menjadikan ASEAN sebagai basis produksi dunia serta menciptakan pasar regional bagi 600 juta penduduknya.

Instrumen penting dan utama dalam mengimplementasikan AFTA adalah Persetujuan Skema Tarif Preferensial Efektif Bersama (Agreement on the Common Effective
Preferential Tariff) atau disingkat CEPT. Skema ini mengatur rincian tentang cakupan dan mekanisme pelaksanaan AFTA. Semua Negara anggota berpartisipasi dalam skema CEPT yang berlaku mulai 1 Januari 1993. Sasarannya adalah penurunan tarif efektif hingga menjadi 0,5\% dalam kurun waktu 15 tahun (1993-2008), namun kemudian dipercepat menjadi tahun 2003, dan terakhir dipercepat lagi menjadi tahun 2002. Selain penurunan tarif hingga 0,5\%, skema CEPT-AFTA juga bertujuan melakukan penghapusan pembatasan kuantitatif dan hambatan-hambatan non tarif lainnya. Skema CEPT-AFTA kemudian dalam rangka pembentukan Masyarakat Ekonomi ASEAN (MEA) tahun 2015 dijadikan ASEAN Trade in Goods Agreement (ATIGA).

Pada tahun 2003, integrasi ekonomi ASEAN semakin kokoh ketika negara-negara anggota ASEAN bertekad mewujudkan sebuah misi yang lebih ambisius yaitu membentuk Masyarakat Ekonomi ASEAN pada tahun 2015. Pertemuan Puncak ASEAN ke-9 di Bali tahun 2003 menghasilkan Bali Concord II yang menegaskan bahwa Masyarakat Ekonomi ASEAN akan diarahkan kepada pembentukan sebuah integrasi ekonomi kawasan. Pembentukan MEA ini diarahkan untuk menjadikan ASEAN sebagai sebuah pasar tunggal (single market) dan yang berbasis produksi (production base), dimana aliran barang, jasa, modal dan tenaga kerja terampil dapat bergerak secara bebas sesuai dengan kesepakatan ASEAN. ${ }^{9}$

Perdagangan preferensial adalah akses khusus yang diberikan oleh satu negara kepada negara lain terhadap suatu produk tertentu. Hal ini dilakukan biasanya melalui pengurangan tarif, namun tidak menghilangkan tarif sama sekali. Pemberian preferensial dalam perdagangan ini dibentuk biasanya melalui perjanjian perdagangan atau blok perdagangan.

8 Paul J. Davidson, Op. Cit. (Note 5), hlm. 74.

9 Lihat ASEAN Economic Community < http://www.asean.org/communities/asean-economic-community> [diakses 7/4/2014]. 
Komitmen untuk mewujudkan MEA, termasuk juga Masyarakat Keamanan ASEAN dan Masyarakat Sosial Budaya ASEAN, ditegaskan juga dalam Piagam ASEAN yang ditandangani oleh semua kepala pemerintahan ASEAN pada tahun 2007 di Singapore. Dalam Preambul Piagam ASEAN disebutkan bahwa:

"Commited to intensifying community through enhanced regional cooperation and integration, in particular by establishing an ASEAN Comminity comprising the ASEAN Security Community, the ASEAN Economic Community and the ASEAN Socio-Cultural Community, as provided for in the Bali Declaration of ASEAN Concord II".

Pada tahun yang sama dengan penandatangan Piagam ASEAN, sebuah cetak biru MEA telah ditandatangani oleh semua kepala pemerintahan ASEAN yang berisi tentang langkah-langkah konkrit yang harus dilaksanakan oleh semua negara-negara anggota ASEAN dalam mewujudkan MEA beserta Jadwal (timeframe) pelaksanaannya.

Lahirnya Piagam ASEAN telah merubah ASEAN dari suatu asosiasi yang longgar menjadi suatu organisasi yang berdasarkan hukum (rules-based) dan berorientasi kepada kepentingan rakyat (people oriented). Pada tahun tahun awal kelahirannya, ASEAN tidak pernah dimaksudkan sebagai sebuah organisasi formal yang operasionalnya terikat dengan ketentuan ketentuan hukum, dan tidak dipandang dalam bingkai aturan dalam konteks kewajiban-kewajiban hukum atau norma yang harus ditaati oleh anggotanya ${ }^{10}$. ASEAN tidak terbiasa berbicara mengani hak dan kewajiban, karena ASEAN tidak pernah dikaitkan dengan hukum internasional dan perjanjian-perjanjian internasional. ASEAN selalu dipandang sebagai sebuah kelompok yang terdiri dari negara negara yang berdaulat yang bekerja berdasarkan prosedur informal dan konsensus yang bersifat ad-hoc dan tidak dalam bingkai aturan-aturan hukum yang mengikat. ${ }^{11}$

Dalam perkembangannya, dan puncaknya ditandai dengan lahirnya Piagam ASEAN, ASEAN tidak lagi sekedar organisasi informal yang pengambilan keputusannya didasarkan pada konsensus, namun secara perlahan sudah didasarkan pada mekanisme formal. Beberapa perjanjian yang bersifat mengikat negara-negara ASEAN telah dibuat dan menjadi landasan hukum bagi operasional kerjasama ekonomi ASEAN. Persetujuan Kawasan Perdagangan Bebas ASEAN (ASEAN Free Trade Agreement) adalah suatu contoh perjanjian yang bersifat mengikat yang ditanda-tangani pada tahun 1992. Dalam pelaksanaan AFTA tersebut beberapa persetujuan telah juga dibuat. ${ }^{12}$ 
Perubahan dalam pengambilan keputusan di ASEAN yang dulunya didasarkan pada konsensus atau musyawarah semata menjadi atas dasar aturan hukum terlihat secara menonjol dalam kerjasama dibidang ekonomi dan perdagangan. Pengaturan kerjasama ekonomi yang didasarkan pada kerangka hukum yang mengikat akan semakin berkembang di masa mendatang sejalan dengan semakin terintegrasinya ASEAN sebagai sebuah komunitas tunggal, terutama menuju Masyarakat Ekonomi ASEAN. ${ }^{13}$

Berbeda dengan konsep negara barat (Uni Eropa) yang lebih mengedepankan legalistik formal dalam proses pengambilan keputusan dan menentukan hak dan kewajiban masing masing pihak, maka ASEAN menggunakan pendekatan dengan cara musyawarah (untuk mencapai) mufakat. Pendekatan yang bersifat informal dan soft ini dikenal sebagai "The ASEAN Way". ${ }^{14}$ Pendekatan yang bersifat soft law telah lama dianggap sebagai karakteristik dari ASEAN dan Asia Timur pada umumnya. Pendekatan musyawarah dan mufakat tercermin dari cara pengambilan keputusan di ASEAN dan struktur organisasi ASEAN.

ASEAN Way dapat dikatakan sebagai cara-cara ASEAN dalam menanggapi dan menanggulangi permasalahan yang ada. Secara sederhana ASEAN Way juga merupakan suatu pembentukan identitas bagi negara-negara Asia Tenggara di tengah maraknya dominasi negara-negara Barat dan juga negara maju. ASEAN Way dapat menjadi suatu pedoman bagi negara Asia Tenggara khususnya untuk bertindak atau dalam menyelesaikan masalah. Beberapa karakteristik dari konsep ASEAN Way antara lain adalah penghormatan terhadap kedaulatan masing-masing negara anggotanya dengan tidak melakukan intervensi terhadap masalah internal negara lain, mengusahakan resolusi konflik dengan cara-cara damai serta tidak menggunakan ancaman kekerasan. Metode yang digunakan dalam manajemen konflik melalui konsep ASEAN Way umumnya didasarkan pada musyawarah atau konsensus. Hal ini untuk mencegah pihak-pihak yang memiliki pengaruh besar untuk bertindak sewenang-wenang.

ASEAN Way mendorong negara-negara di kawasan Asia Tenggara untuk mencari cara untuk bekerja sama secara maksimal dengan cara dialog serta konsultasi. Proposal dari Thailand untuk "flexible engagement" di tahun 1998 merupakan terobosan baru untuk perubahan cara diplomasi di ASEAN. Flexible engagement yang dimaksud di atas adalah perbincangan yang dilakukan oleh negara-negara anggota ASEAN untuk membicarakan tentang masalahmasalah domestik serta kebijakan didalam negeri negara anggota ASEAN tanpa ada maksud untuk mengintervensi negara satu sama lain. Proposal dari Thailand tersebut awalnya tidak diterima oleh negara-negara anggota ASEAN, kecuali Filipina, karena menganggap proposal tersebut sebagai pelanggaran intervensi isu domestik suatu negara.

Selain itu, mekanisme yang digunakan adalah pendekatan secara informal. Pendekatan secara

\footnotetext{
13 Paul J. Davidson, "The ASEAN Way and the Role of Law in ASEAN Economic Cooperation", 8 Singapore Year Book of International Law, 2004. hlm. 165.

14 Rodolfo C. Severino, Sekretaris Jenderal ASEAN, the ASEAN Way and the Rule of Law, makalah lepas yang disampaikan pada International Law Conference on ASEAN Legal Systems and Regional Integration yang diselenggarakan oleh Universitas Malaya, Kuala Lumpur, 3 September 2001.
} 
informal ini dimaksudkan agar mencairkan ketegangan yang umum terjadi pada pihak-pihak yang berselisih. Dengan memanfaatkan nilai positif dari mekanisme ini, maka penyelesaian konflik dengan cara-cara yang damai dapat dicapai.

Namun demikian, dalam konteks kerjasama ekonomi internasional, pendekatan ASEAN way mulai dikaji kembali efektifitasnya. Dalam praktek dewasa ini, model pendekatan yang dilakukan dalam menata hubungan ekonomi dan perdagangan internasional umumnya menggunakan kerangka hukum (rules-based). Dalam banyak isu menyangkut ekonomi dan perdagangan, terdapat kecenderungan pengaturannya melalui pembuatan perjanjian perjanjian internasional yang bersifat mengikat secara hukum (legally binding), sebagaimana direfleksikan oleh WTO. Kerangka hukum WTO tidak saja menyangkut isi atau substansi pengaturan perdagangan, tetapi juga menyediakan mekanisme penyelesaian sengketa melalui Badan Penyelesaian Sengketa (DSB), lembaga panel dan banding.

Hukum dan sistem hukum adalah faktor penting bagi kemajuan ekonomi. Hukum dan kelembagaan hukum dapat mendorong kegiatan ekonomi. Rodolfo C Severino, mantan Sekjen ASEAN mengatakan bahwa jika kerjasama ekonomi ingin lebih substansial dan berdampak nyata, maka perjanjian-perjanjian yang dibuat haruslah mempunyai kekuatan mengikat. ${ }^{15}$ Hukum mempunyai 4 tujuan dalam konteks pembangunan ekonomi, yaitu (1) hukum memberikan argumen dan menopang hak, kewajiban, dan tanggung jawab para pihak dalam bisnis, (2) para pelaku bisnis akan mampu menjalankan transaksi bisnisnya dengan tingkat kepastian dan prediktibilitas yang masuk akal, (3) hukum memberikan sarana atau jalan memperoleh hak-hak secara sah, dan (4) yang terpenting adalah menumbuhkan raya percaya dalam bisnis. Sebailkya, sistem hukum yang tidak efektif akan meningkatkan biaya transaksi. ${ }^{16}$

Dengan perkembangan dan perluasan kerjasama ekonomi yang semakin meningkat di ASEAN dan juga mengingat perkembangan perdagangan internasional dan investasi di tingkat global yang semakin banyak diatur oleh peraturan dan sistem hukum internasional, maka mendorong ASEAN untuk merubah cara pendekatannya. Perubahan ASEAN menjadi lebih legalistik bukan saja didorong oleh keinginan mewujudkan organisasi yang lebih terintegrasi, tetapi juga dikarenakan adanya keinginan untuk menjadikan ASEAN sebagai sebuah pasar regional yang lebih menarik bagi investasi asing. Agar dapat menarik investor asing maka negara-negara ASEAN perlu menyediakan kerangka hukum yang memadai untuk menjamin hak-hak para investor.

Oleh karena itu, dalam perjalanannya, ASEAN secara perlahan-lahan mulai menggunakan pendekatan hukum dalam mengatur hubungan kerjasama diantara anggotanya. Perjanjian pertama yang dilahirkan oleh ASEAN adalah Perjanjian Persahabatan dan Kerjasama di Asia Tenggara atau TAC (Treaty of Amity and Cooperation in Southeast Asia) pada tahun 1976, hampir sembilan tahun sejak berdirinya 
ASEAN. Sepuluh tahun kemudian (1977) baru dihasilkan satu perjanjian lagi yaitu Persetujuan Pengaturan Perdagangan Preferensial (PTA). Sepuluh tahun berikutnya, yaitu pada tahun 1987, disepakati Persetujuan Promosi dan Perlindungan Investasi. ${ }^{17}$ Tentu saja perjanjian penting yang harus disebutkan disini adalah Perjanjian CFPT-AFTA (1992), yang menjadi kerangka hukum yang kokoh bagi terwujudnya integrasi ekonomi ASEAN.

Perubahan ke arah pendekatan yang lebih formal legalistik tidak berhenti sampai dengan lahirnya perjanjian CEPT-AFTA, namun ASEAN melangkah lebih jauh lagi dengan menyepakati sebuah Piagam ASEAN yang secara ekplisit menyatakan bahwa "Hereby decide to establish, through this Charter, the legal and institutional framework for ASEAN".18 Dengan demikian, Piagam ASEAN ini bukan saja menjadi kerangka hukum dan kelembagaan ASEAN dalam operasionalnya, tetapi juga secara implisit mengakui dan mengarahkan ASEAN sebagai sebuah organisasi yang berdasarkan hukum (rules based).

Lahirnya Piagam ASEAN adalah merupakan sejarah penting yang akan mewarnai perkembangan ASEAN ke depan. Selain mengubah organisasi ASEAN yang sebelumnya bersifat longgar dan informal menjadi organisasi yang berlandaskan hukum, Piagam ASEAN dapat juga berfungsi sebagai: (1) konstitusi ASEAN, (2) identitas hukum ASEAN, (3) kerangka kelembagaan ASEAN, (4) kodifikasi norma, aturan dan nilai nilai ASEAN, (5) landasan bagi pembentukan Masyarakat ASEAN, (6) kerangka kerja organisasi/institusi agar lebih efektif dan efisient, (7) pendorong peningkatan peran dan fungsi Ketua ASEAN, Sekjen dan Sekretariat ASEAN, (8) upaya meningkatkan identitas dan menciptakan solidaritas warga ASEAN, (9) penguatan hubungan eksternal ASEAN dan peningkatan posisi yang sama diantara anggota ASEAN, dan (10)pendorong terwujudnya mekanisme penyelesaian sengketa yang tepat dan efektif di ASEAN. ${ }^{19}$

\section{Mekanisme Penyelesaian Sengketa}

Salah satu hal penting yang diatur dalam Piagam ASEAN adalah memberikan aturan mengenai kerangka hukum bagi penyelesaian sengketa diantara negara-negara anggota ASEAN. Pada bagian pembukaan dari Piagam ASEAN dinyatakan bahwa dengan menghormati persahabatan dan kerjasama serta prinsipprinsip yang terdapat dalam TAC dengan beberapa prinsip-prinsip tambahan yaitu bersatu dalam perbedaan serta konsensus. Dalam konteks regional ASEAN, ada beberapa prinsip penyelesaian sengketa yang dituangkan dalam beberapa instrumen hukum dan Piagam

17 Dari tahun 1977 sampai tahun 1987, telah lahir juga beberapa perjanjian, diantanya ASEAN Industrial Projects (1980), the ASEAN Industrial Complementation (1981), the ASEAN Industrial Joint Ventures (1983), the Brandto-Brand Complementation Scheme (1988), ASEAN Currency Swap Arrangement (1977), Agreement on the Food Security Reserve (1979), Agreement on the Mutual Recognition of Drivers' Licenses (1985), dan Establishment of the Petroleum Security Reserve (1986).

18 Lihat di bagian Pembukaan Piagam ASEAN.

19 Rosario Gonzalez-Manalo, "Drafting ASEAN'sTomorrow: The Eminent Persons Group and the ASEAN Charter", dalam Tommy Koh, (eds.), The Making of The ASEAN Charter, (Singapore: World Scientific Publishing Co.Pte.Ltd., 2009), hlm. 3. 
ASEAN. Dalam konteks tersebut, mekanisme penyelesaian sengketa yang ditekankan di ASEAN lebih memilih cara-cara damai, sebab selain hal itu menguntungkan para pihak yang bersengketa, juga berimplikasi positif terhadap stabilitas keamanan di wilayah kawasan. Selain itu, faktor sejarah ASEAN yang lahir karena keprihatinan yang timbul kala itu, dimana negara-negara di kawasan ini sangat rentan konflik yang melibatkan kepentingan negaranegara besar pasca Perang Dunia II. Atas dasar itulah berbagai perjanjian kerjasama dalam bingkai ASEAN selalu dilakukan dengan cara penekanan pada penggunaan cara-cara damai dalam penyelesaiannya, ketika terjadi sengketa. $\mathrm{Hal}$ ini tercemin juga dalam Piagam ASEAN yang sudah ditandatangani dan diberlakukan bagi negara anggota-anggota ASEAN.

ASEAN didirikan dengan tujuan untuk "maintain and enhance peace, security and stability and further strengthen peace-oriented values in the region". Hal ini dinyatakan dalam Pasal 1 Ayat 1 Piagam ASEAN. ASEAN adalah sebuah komunitas, bukan sekedar sebuah kelompok negara-negara yang disatukan karena kedekatan geografis. Tujuan utamanya adalah untuk menciptakan rasa kebersamaan dimana masing masing anggota merasa menjadi bagian dari sebuah keluarga negara negara di belahan Asia Tenggara yang dihubungkan secara budaya, politik dan ekonomi. Untuk mencapai tujuan tersebut maka perlu ada sebuah mekanisme penyelesaian sengketa secara damai. Namun ada kalanya setelah berbagai upaya damai dijalankan, penyelesaian sengketa secara damai tersebut tidak tercapai. Dalam konteks hukum nasional, terdapat berbagai metode penyelesaian sengketa. Penyelesaian sengketa melalui konsultasi atau negosiasi adalah metode yang umum dilakukan sebelum dilakukannya upaya penyelesaian yang lain. Kemudian apabila konsultasi atau negosiasi tidak berhasil, para pihak dapat membawa sengketanya kepada mekanisme penyelesaian sengketa lainnya lainnya seperti mediasi, konsialiasi, arbitrase dan bahkan ke pengadilan.

Sangatlah tidak realistis apabila kita membayangkan bahwa sengketa-sengketa yang timbul diantara negara-negara anggota ASEAN akan semuanya dapat diselesaikan secara damai atau melalui musyawarah untuk mencapai mufakat, yang bersifat informal. Pengalaman organisasi internasional lain atau ASEAN sendiri tidaklah mendukung thesis tersebut. Tidak ada jaminan bahwa semua sengketa akan dapat diselesaikan secara efektif melalui cara konsultasi atau negosiasi. Mekanisme penyelesaian sengketa yang "lebih" diperlukan. Oleh karena itulah maka Pasal 22 Ayat 2 Piagam ASEAN menyatakan bahwa ASEAN perlu membuat dan mempertahankan mekanisme penyelesaian sengketa bagi semua sengketa yang timbul dari kerjasama ASEAN di semua bidang. Apabila ada instrumen ASEAN tertentu memuat suatu mekanisme penyelesaian sengketa maka hal yang wajar apabila sengketa yang masih dalam cakupan instrumen bersangkutan diselesaikan menurut cara yang disebutkan dalam instrumen tersebut. Hal ini diatur dalam Pasal 24 Ayat 1 Piagam ASEAN. Sebagai contoh Perjanjian Kerangka Peningkatan Kerjasama Ekonomi ASEAN (the Framework Agreement on Enhanching ASEAN Economic Cooperation) 1992 menyebutkan dalam Pasal 9 bahwa:

"any differences between Member States
concerning the interpretation or application
of this Agreement ... shall, as far as possible,
be settled amicably between the parties.
Where necessary, an appropriate body shall
be designated for thesettlement of disputes". 
Pasal ini diperluas secara signifikan oleh Protokol tentang Mekanisme Penyelesaian Sengketa 1996, yang kemudian digantikan oleh Protokol ASEAN tentang Mekanisme Penyelesaian sengketa yang Ditingkatkan Tahun 2004 atau yang dikenal sebagai Protokol Vientiane. ${ }^{20}$ Protokol Vientiane adalah mekanisme penyelesaian sengketa yang paling penting karena mencakup semua perjanjianperjanjian ekonomi ASEAN. Selanjutnya Pasal 22 Ayat 3 mengatur kembali bahwa apabila tidak diatur sebaliknya, sengketa menyangkut interpretasi atau penerapan dari perjanjianperjanjian ekonomi ASEAN harus diselesaikan menurut ketentuan dalam Protokol ASEAN mengenai Mekanisme Penyelesaian Sengketa yang Ditingkatkan. Inti dari Protokol Vientiane adalah memberikan aturan mengenai pembentukan Panel untuk memeriksa sengketa dan mencari fakta-fakta untuk membantu Ekonomi Senior. Pertemuan Pejabat Ekonomi Senior akan memberikan putusan. Panel pada dasarnya akan mempertimbangkan sifat dari sengketa dan memutuskan bagaimana sengketa tersebut sebaiknya diselesaikan. Hal yang penting dicacat disini adalah bahwa dalam sengketa menyangkut perjanjian atau persetujuan ekonomi terdapat suatu mekanisme penyelesaian sengketa yang bersifat formal.

Dalam hal dimana sengketa tidak terkait dengan persetujuan ASEAN, Pasal 24 Ayat 2 menyatakan bahwa cara penyelesaian sengketa yang diatur dalam Perjanjian Persahabatan dan Kerjasama di Asia Tenggara (TAC) beserta hukum acaranya akan diberlakukan. TAC menegaskan bahwa sengketa yang mengancan perdamaian harus diajukan ke Dewan Tinggi (High Council) yang beranggotakan perwakilan dari semua pihak dalam sengketa. Namun ini hanya dapat dilaksanakan kalau para pihak menyetujuinya. Alternatif lain adalah para pihak dapat mengajukan sengketanya menurut cara penyelesaian damai sebagaimana diatur dalam Pasal 33 Ayat 1 Piagam PBB.

Dalam ketentuan pada Pasal 28 Piagam ASEAN ditegaskan, kecuali yang diatur sebaliknya di dalam Piagam ini, negara-negara anggota berhak untuk beralih ke cara-cara penyelesaian sengketa secara damai seperti tercantum dalam Pasal 33 ayat 1 dari Piagam Perserikatan Bangsa-Bangsa atau instrumen hukum internasional yang lain yang ada didalamnya negara-negara anggota yang bersengketa merupakan para pihak. Dalam pasal tersebut ditegaskan ada tiga pilihan model penyelesaian sengketa yang bisa dilakukan oleh para anggota ASEAN. Pertama, para pihak terlebih dulu harus mengupayakan mekanisme penyelesaian sengketa melalui prosedur yang disediakan dalam Piagam ASEAN, sebagaimana telah diuraikan dalam ketentuan Pasal 22 sampai dengan Pasal 28. Kedua, para pihak yang notabenenya juga merupakan anggota PBB dapat menggunakan ketentuan dalam Pasal 33 ayat 1 Piagam PBB dalam penyelesaian sengketa secara damai di antara mereka. Ketiga, selain itu melalui kedua mekanisme tersebut para pihak dapat menggunakan cara-cara penyelesaian sengketa yang diatur dalam ketentuan hukum internasional lainnya.

20 Lihat the ASEAN Protokol on Enhanced Dispute Settlement Mechanism, diakses melalui <http://www.asean.org/ news/item/asean-protocol-on-enhanced-dispute-settlement-mechanism>, (diakses 10 Juni 2014). 
Dengan cara ini memungkinkan sengketa tersebut dibawa ke pada Mahkamah Internasional (International Court of Justice) di Den Hague. Mekanisme inilah yang dipergunakan oleh Malaysia dan Indonesia ketika kedua negara tersebut bersengketa menyangkut Pulau Sipadan dan Ligitan. Demikian pula, sengketa Malaysia dan Singapore menyangkut Pedra Branca diselesaikan oleh Mahkamah Internasional.

Dari uraian di atas, dapatlah dikatakan bahwa ketentuan pada Pasal 22 sampai dengan Pasal 28 dalam Piagam ASEAN yang mengatur mengenai mekanisme penyelesaian sengketa di ASEAN adalah merupakan repetisi dari Pasal 13 sampai dengan Pasal 17 TAC dan merupakan salinan dari Pasal 33 Piagam PBB. $\mathrm{Hal}$ ini dijelaskan dan ditegaskan dalam Pasal 38 Piagam ASEAN yang merujuk Piagam PBB dalam mekanisme penyelesaian sengketa.

Tidak semua instrumen ASEAN mengatur tentang penyelesaian sengketa, oleh karena itu diperlukan pengaturan yang dapat mencakup semua hal. Maka dari itu Pasal 25 Piagam ASEAN memberikan jalan keluar yaitu bahwa mekanisme penyelesaian sengketa yang pantas, termasuk arbitrase, harus dibentuk untuk menyelesaikan sengketa-sengketa mengenai interpretasi atau penerapan Piagam ASEAN dan instrumen ASEAN lainnya. Bentuk yang pasti dari mekanisme penyelsaian sengketa sebagaimana diatur dalam Pasal tersebut belum dapat ditentukan. Berdasarkan laporan dari Eminent Persons Group Pembentukan Piagam ASEAN dinyatakan bahwa terdapat rekomendasi agar mekanismenya mengikuti Protokol Vientiane. Terdapat diskusi yang panjang mengenai kemungkinan menggunakan ajudikasi dan arbitrase, namun diputuskan bahwa ASEAN belum siap untuk menggunakan mekanisme pengadilan. Pada saat itu disepakati bahwa mekanisme yang mungkin lebih pas adalah dengan mengikut model Protokol Vientiane. Namun demikian, Pasal 25 Piagam ASEAN memberikan peluang kepada ASEAN untuk menggunakan pengadilan di kemudian hari apabila dapat dibuktikan bahwa memang diperlukan sebuah mekanisme pengadilan.

\section{Penutup}

Sejak periode awal kelahirannya, ASEAN tidak terbiasa mengatur hubungan diantara anggota-anggotanya dalam sebuah kerangka hukum yang bersifat mengikat, namun lebih mengedepankan pelaksanannya atas dasar saling pengertian dan kesepakatan kesepakatan yang bersifat informal. Sejak awal negara negara pendiri ASEAN memang tidak ingin membuat sebuah organisasi regional yang kuat dengan menyerahkan kekuasaannya kepada organisasi baru ASEAN. Negara-negara anggota masih ingin tetap mempertahankan secara ketat masing masing kedaulatannya.

Pendekatan yang bersifat soft law telah lama dianggap sebagai karakteristik dari ASEAN. Pendekatan musyawarah dan mufakat tercermin dari cara pengambilan keputusan di ASEAN dan struktur organisasi ASEAN. Pendekatan "ASEAN way" ini berbeda dengan model pendekatan yang dilakukan dalam menata hubungan ekonomi dan perdagangan internasional yang umumnya menggunakan kerangka hukum (rules-based). Dengan perkembangan dan perluasan kerjasama ekonomi yang semakin meningkat di ASEAN dan juga mengingat perkembangan perdagangan internasional dan investasi di tingkat global yang semakin banyak diatur oleh peraturan dan sistem hukum internasional, maka mendorong ASEAN untuk merubah cara pendekatannya. 
ASEAN secara perlahan lahan tapi pasti sudah mulai menata hubungan dan kerjasama ekonominya diantara negaranegara anggotanya melalui kesepakatankesepakatan yang dirumuskan dalam suatu aturan hukum (persetujuan/agreement) yang bersifat mengikat (legally binding). Pendekatan formal legalistik initidak saja dalam konteks menciptakan aturan hukum untuk mengatur hak dan kewajiban para pihak (negara negara anggota ASEAN), namun juga digunakan dalam konteks menegakkan kesepakatan-kesepakatan (aturan-aturan hukum) yang telah dibuat oleh ASEAN. Mekanisme penyelesaian sengketa di ASEAN saat ini, walaupun masih tetap mengutamakan proses penyelesaian sengketa secara damai, telah memberikan ruang kepada negara negara anggota ASEAN untuk menempuh proses yang lebih formal dan legalistik.

Sebelum lahirnya Piagam ASEAN, terdapat beberapa mekanisme penyelesaian sengketa. Selain TAC, terdapat Protokol ASEAN mengenai Penyelesaian Sengketa tahun 2004dan Protokol dari Piagam ASEAN tentang Mekanisme Penyelesaian Sengketa tahun 2010. Protokol ini memberikan mekanisme untuk membantu anggota negara ASEAN dalam menyelesaikan sengketannya menyangkut interpretasi dan pelaksanaan Piagam ASEAN. Penyelesaian yang diatur dalam protokol dapat berupa penyelesaian non ajudikasi sampai dengan kuasi judisial, seperti konsultasi, good offices, mediasi, konsiliasi, dan arbitrase. Namun belum diatur mengenai penyelesaian melalui pengadilan.

Di tengah kompetisi global yang semakin ketat dan dalam rangka mewujudkan integrasi ekonomi ASEAN, sudah waktunya ASEAN memiliki mekanisme yang jelas baik dalam proses pengambilan keputusan maupun dalam penyelesaian sengketa, dan tidak lagi mengandalkan dengan apa yang disebut the ASEAN Way.

Ketika ASEAN dewasa ini mengembangkan aturan hukum untuk mengatur hubungan dan kerjasama (ekonomi) diantara mereka, pekerjaaan rumah yang harus dilakukan negara-negara Anggota ASEAN saat ini adalah mengimplementasikan kesepatan-kesepakatan yang telah dituangkan dalam berbagai perjanjian ASEAN ke dalam hukum nasional masing masing negara ASEAN. Perlu ada mekanisme kontrol oleh sebuah badan ASEAN untuk memastikan bahwa negara-negara anggota ASEAN dalam mengeluarkan aturan dan kebijakan ekonominya telah sesuai dengan perjanjian ASEAN.

Pendekatan legal formalistik yng sedang dijalankan oleh ASEAN saat ini akan jauh lebih efektif apabila secara gradual dilakukan pula harmonisasi hukum untuk bidang-bidang hukum tertentu. Implementasi sebuah perjanjian (ekonomi) ASEAN, baik dalam kerangka penyusunan regulasi nasional maupun dalam konteks pelaksanaan aturan di lapangan, akan lebih mudah apabila hukum hukum negaranegara ASEAN telah harmonis.

\section{DAFTAR PUSTAKA}

\section{Buku}

Bucklin, William, Regional Economic Cooperation in Southeast Asia (Ann Arbor: University Microfilms International, 1975)

Davidson, Paul J., ASEAN-The Evolving Legal Framework fo Economic Cooperation, (Singapore: Times Academic Press, 2002)

Davidson, Paul J., The Legal Framework for International Economic Relations, (Singapore: Institute of Southeast Asian Studies, 1997)

Koh, Tommy (eds.), The Making of The ASEAN Charter, (Singapore: World Scientific Publishing Co.Pte.Ltd., 2009) 


\section{Makalah/Artikel}

Rajenthran, Arumugam, An Overview of the Legal Framework for Foreign Direct Investment, (Economics and Finance, No. 2, 2002)

Severino, Rodolfo C., Sekretaris Jenderal ASEAN, the ASEAN Way and the Rule of Law, (Makalah lepas yang disampaikan pada International Law Conference on ASEAN Legal Systems and Regional Integration yang diselenggarakan oleh Universitas Malaya, Kuala Lumpur, 3 September 2001)

\section{Website}

ASEAN Economic Community < http://www.asean. org/communities/asean-economic-community> [diakses 7/42014].
ASEAN Protokol on Enhanced Dispute Settlement Mechanism, diakses melalui <http://www. asean.org/news/item/asean-protocol-onenhanced-dispute-settlement-mechanism>, [10/06/2014].

ASEAN: $\quad$ http://www.asean.org/resources/ publications/item/association-of-southeastasian-nations-asean-integration-monitoringreport-a-joint-report-by-the-asean-secretariatand-the-world-bank-english?category_id=382, [diakses 2/3/2014].

The Asean Declaration (Bangkok Declaration) Bangkok, 8 August 1967, diakses melalui http://www.asean.org/news/item/the-aseandeclaration-bangkok-declaration, [diakses 3/4/ 2014]. 